\title{
Perspective on Sub-national Governance of Crossborder Regions: Democratic Governance in Anti-democratic Times?
}

\author{
Sara Svensson * \\ School of Education, Humanities and Social Sciences, Halmstad University, Halmstad, Sweden
}

In the past decades, subnational cooperation between municipalities and regions has become more common all over the world. In Europe and its neighborhood this tendency has been especially visible, much due to policy advocacy and technical assistance by regional intergovernmental organizations such as the Council of Europe, the European Union and the Organization for Security and Cooperation in Europe. This development accelerated in the 1990s in tandem with the transition and democratization processes that started after the fall of the Soviet Union. However, in many places democratization has

OPEN ACCESS

Edited by:

Inna Menykovska,

Central European University, Hungary

Reviewed by:

Bojan Vranic,

University of Belgrade, Serbia

Harlan Koff,

University of Luxembourg, Luxembourg

*Correspondence:

Sara Svensson

sara.svensson@hh.se

Specialty section:

This article was submitted to

Peace and Democracy,

a section of the journal

Frontiers in Political Science

Received: 17 May 2021 Accepted: 16 September 2021 Published: 28 September 2021

Citation:

Svensson S (2021) Perspective on

Sub-national Governance of

Crossborder Regions: Democratic Governance in Anti-democratic

Times?.

Front. Polit. Sci. 3:710923. doi: 10.3389/fpos.2021.710923 stopped or started to reverse, leading to backsliding away from democracy. While democracy has always been different in crossborder regions due to the special status of their governance arrangements, this new development accentuates a need for new tools to understand the implications of various threats to democracy for the future of crossborder cooperation. This Perspective article provides an overview of the literature on participatory governance and democracy with relation to border regions, and suggests some mechanisms whereby current backsliding developments might harm sub-national cross-border democracy and a way by which current indexes of democracy at the national level could be adapted to the "messy" spaces of cross-border regional governance. This allows the Perspective article to be useful to both further research in the area and policy practitioners. Empirical examples from Central and Eastern Europe, are used as illustrations.

Keywords: sub-national democracy, cross-border cooperation, cross-border regions, democratic deficit, backsliding democracy

\section{INTRODUCTION}

In the past decades, subnational cross-border cooperation between municipalities and regions has become more common. Since local sub-national cross-border cooperation stopped being framed or regulated as "illicit" diplomacy, or para-diplomacy, conducted by "subversive" subnational actors (Aldecoa and Keating, 1999), it has been seen as positive for regional economic and democratic peaceful development. In Europe and its neighborhood this tendency has been especially visible, much due to policy advocacy and technical assistance by regional intergovernmental organizations such as the Council of Europe, the European Union and the Organization for Security and Cooperation in Europe (Perkmann, 2002; Medve-Bálint and Svensson, 2013). This development accelerated in the 1990s in tandem with the transition and democratization processes that started 
after the fall of the Soviet Union. However, in many places, democratization has stopped or started to reverse, leading to backsliding away from democracy. While democracy has always been different in cross-border regions due to the special status of their governance arrangements, this Perspective article contributes to the Research Topic "Challenges to Local Democracy" by arguing that the specific body of literature that deals with cross-border sub-national cooperation needs a new approach and new tools to understand the implications of various threats to democracy for the future of cross-border cooperation.

The article starts with a brief review of the literature on democratic backsliding within Europe, illustrated with research on Hungary as the most prominent example. It continues with a review of the literature on participatory governance and democracy with relation to border regions. This leads to a suggestion of the mechanisms whereby current backsliding developments might harm sub-national cross-border democracy and a way by which current indexes of democracy at the national level could be adapted to the "messy" spaces of cross-border regional governance.

\section{DEMOCRACY UNDER THREAT}

Globally, democracy has been in retreat for well over a decade (Freedom House, 2021) and the average global quality of democracy is down to levels last since in the early 1990s (VDem, 2021). There is increasing concern that democracy - a governing method that is based on inclusion in decision-making procedures of those that are governed, with institutional protections in place for minorities and pluralistic opinionformation - is under threat. While Europe's democracies are generally holding up, even members of the European Union have experienced backsliding, first and foremost among them Hungary, which by Freedom House is assessed as only "partly free." The radicalization of national conservatism in Hungary, under the leadership of prime minister Viktor Orbán, is well documented to the extent that it has become a poster child for the term "democratic backsliding" (Sitter and Bakke, 2019; Greskovits, 2015; Krekó and Enyedi, 2018; Batory and Svensson, 2019; Dimitrova, 2018; Bánkuti et al., 2012; Halmai, 2011; Bogaards, 2018). Scholars have noted the peculiar development of the ruling party Fidesz, which has been described as "the earliest example of a radicalising centre-right party that in less than a decade transformed a liberal democratic into a competitive authoritarian regime within the European Union" (Greskovits, 2020: 247). The term "democratic backsliding" refers to increasing deficits in the institutional structure of democracy, usually taken to be the result of deliberate action by actors in power. For instance, Bermeo's definition of democratic backsliding as "state-led debilitation or elimination of any of the political institutions that sustain an existing democracy" (Bermeo, 2016:5) fits the development of Hungary where the state equals the ruling party (Krekó and Enyedi, 2018).

It is often pointed out that the development in Hungary is part of a global backsliding trend, where the quality of democracy has decreased in many countries and some countries have been labelled hybrid regimes rather than full democracies. The assessments of Freedom House (2021) and the Quality of Democracy monitoring project at the University of Gothenburg are among the more well-known. There are obvious challenges to maintaining or building local democratic governance structures in backsliding democracies, hybrid regimes or (near) authoritarian regimes. However, the sub-national dimension of these has not received the same amount of attention. For instance, in the years 2019-2020, the journal Local Government Studies published nothing that engaged indepth with de-democratization or threatened democracies. What has been done is recent and largely been on regional variation in the quality of democracy, where initial studies show that differences within countries may be larger than between countries (e.g., Charron and Lapuente, 2013; Charron et al., 2018). Two recent articles in Governance have sought to advance this agenda by going more local. Erlingsson and Lundåsen, 2021 argues that more research is needed on municipal variation in quality of argument and brings forward a study on institutional quality and trust based on data from Sweden (2021). The other paper pursues an inquiry into Hungarian local democracy under the Orbán regime. The University of California/Berkely-based researchers Laura Jakli and Matthew Stenberg combined a document analysis of the organizational and operational rules that govern Hungarian city councils with interviews with local elites. They found that many changes have been made at the local level that reduce the opportunities for opposition parties to partake equally in the public sphere (Jakli and Stenberg, 2021). They argue that understanding the subnational level is crucial to understanding how illiberal and/or hybrid regimes such as Hungary has kept oppositional activity and a functioning viable opposition option at bay. In their view, incremental subnational feedback loops of illiberalism prop up the regimes. "Illiberal leaders place numerous, systematic subnational constraints on local democratic bodies and institutions to protect against the emergence of local political resilience" (Jakli and Stenberg, 2021:316).

\section{IMPLICATIONS FOR CROSS-BORDER GOVERNANCE}

Given the scarcity of scholarship on the sub-national level, it is not surprising that democratic backsliding of the governance in borderlands is hitherto an un-examined topic. While the international borderlands studies community has grown over the past half-century, it has not reached mainstream social science, especially not in the political science discipline. That is unfortunate, since borderlands constitute interesting sites of differential governance dynamics with heavy normative connotations. In Europe they have special links to the European integration project and are sometimes seen as "laboratories of integration" (Knippenberg, 2004; Kramsch and Dimitrovova, 2008; Stokłosa, 2015).

Even within countries, regional governance can be "messy" (Öjehag-Pettersson, 2017; Olausson and Wihlborg, 2018). Often, 
many institutional layers and actors are involved, especially around broad issues such as regional development. Political power and distributional debates may be easily obstructed behind facades of technocratic administrative rule (Keating, 2009). Regional governance arrangements that span national borders by necessity becomes even more messy, while still being shaped by administrative-technocratic action patterns. In European borderlands, cross-border cooperation organizations that comprise local governments and regions, sometimes also civil or economic actors, may have been increasingly tolerated and promoted, but understanding how they fit into broader institutional arrangements are not easy. These "Euroregions", to use a common term (Svensson, 2013), can be seen as both networks of actors (mainly local or regional governments), and as unitary policy actors. As organizational actors they exist within a broader network of other organizational players relevant to policy-decisions taken in the cross-border landscape. This is a view of Euroregions fitting in with the multi-level governance view of Europe (Marks, 1993:392, 402-40; Hooghe and Marks, 2001) as well as on the emphasis on the role of policy networks in policymaking (Börzel, 1998:254; Christopoulos, 2006:786; Lynn, 2012). For the study of Euroregions, the distinction between two types of multiple-level arrangements, type 1 and Type 2 (Hooghe and Marks, 2003), is especially relevant. The former "describes system-wide governing arrangements in which the dispersion of authority is restricted to a limited number of clearly defined, nonoverlapping jurisdictions at a limited number of territorial levels, each of which has responsibility for a "bundle" of functions. By contrast, Type II describes governing arrangements in which the jurisdiction of authority is task-specific, where jurisdictions operate at numerous territorial levels and may be overlapping (Bache, 2012:630). The complex governance in borderlands is mostly referred to as Type 2 (e.g., Medeiros, 2020:151).

At the same time, many have been concerned with the lack of democratic legitimacy these arrangements may have. Crossborder regional bodies are not directly elected. Even though legitimacy is indirectly conferred through the participation of politically elected representatives of involved regions and local governments, the accountability mechanisms may be too far removed to appear effective or realistic. Many citizens may not even be aware that the Euroregions exist (Trillo-Santamaría, 2014). Moreover, as argued by Ulrich (2020:171), also the comprehensive Type 2 approach to multi-level governments often neglect the normative-ontological perspective of governance that emphasize the participation of civil society and citizens in the whole area of the borderlands. Even when such participation is desired and sought for, many border regions lack a cross-border civil society network, meaning that civil society organizations look differently and/or lead separate lives on each side of the border. The structural inequivalence between civil society organizations on two sides of the border can be significantly larger than it is between government organizations. On the other hand, to achieve results Euroregions must relate to significant amounts of hierarchical jurisdiction within the multilevel governance frameworks, more akin to Type 1, since they have only very limited decision-making powers of their own. Their scope of action is therefore limited. In addition, European Union incentive structures for cross-border cooperation have neglected value-based normative aspects (e.g., Nadalutti, 2017; Nadalutti, 2020).

The academic literature has so far analyzed these and similar democratic deficits of cross-border governance mainly within the context of consolidated well-functioning national democracies. Among the professional discussions among policymakers on the future of cross-border governance, anti-democratic political forces and national contexts in which democracy backslide is treated as an ignored elephant in the room. But to understand contemporary and future cross-border governance, it is essential to include a discussion on what kind of effect de-democratic processes can have. Such analysis should consider the following points:

Firstly, authoritarian tendencies often go hand in hand with re-centralization of power to national capitals and those in charge there. However, it is worth noting that the correlation is not strong. Despite significant reductions in the quality of democracy, the trend in regional authority is towards more - not less - power at the meso-level. The only comparative index that has systematically measured decentralization to regional level has found that out of 81 countries that are included in the index, 52 still experienced a net increase in the degree of regional authority at the last survey date, and less than ten experienced a decline. At the same time the development in countries with hybrid or authoritarian regimes needs to be monitored (Schakel et al., 2018; OECD, 2019). When local and regional powers are revoked, their competence to reach out across national borders will de facto decline and chances to get things done decrease. Secondly, current authoritarian tendencies are often crafted within strong nationalist framing techniques. Such nationalist narratives may in themselves impact negatively on the chances for the cross-border arrangements to create democratic bottom-up legitimate endeavors. Thirdly, the fragile indirect legitimacy of cross-border governance may be harmed. Local and regional actors may ideologically align with anti-democratic sentiments, which would make even the indirect legitimacy weaker. Moreover, reduced democratic legitimacy of actors on one side of the border may decrease the legitimacy of the entire regional governance development program. This may therefore require attention by a multitude of actors and should be discussed openly.

To assess the extent to which these potential mechanisms of how democratic backsliding might harm the democratic quality of sub-national cross-border cooperation, one needs to work with ways to measure democracy even in these complex environments. The regional authority index mentioned above is not suitable for assessing cross-border regions, since it only considers formal sharing arrangements and competences. However, some of the various ways in which the quality of democracy is regularly measured would be possible to adapt for usage in "messy" cross-border regional spaces. For instance, Freedom Houses assesses political rights and civil rights based upon electoral process, political pluralism and participation, functioning of government, freedom of expression, associational rights, rule of law and personal autonomy and individual rights (Freedom House, 2021). Some of these indicators could be assess for the whole cross-border region, whereas other would need to be combined based on the two (or three) different national 
territories involved. Likewise, the V-Dem Quality of Governance project works with five different dimensions of democracy (electoral, liberal, participatory, deliberative, and egalitarian) where at least the last three could be adapted for cross-border governance assessment purposes. An advantage of both is that they generally work with expert surveys, which to some extent can mitigate the well-known problem of lack of statistical data even in highly developed cross-regional spaces (Nordic Co-operation, 2021). The creation of such an index is an urgent task for researchers working in the area, since it would allow for systematic comparative assessment of both the quality of democracy in cross-border regions when democracy is threatened, and the action space available for local actors. If it were to be combined with more attention to policy positions through studying voting patterns of borderland citizens, we would know more not only about mechanisms of democracy, but in the European context also about Europeanization. The benefit of this would reach beyond academia to policymakers and policy practitioners in the field.

\section{CONCLUDING REMARKS}

For decades European policymakers have promoted the capacity and possibility for sub-national actors to meet, interact and collaborate with corresponding actors on the other side of national borders. This has been done on the premise that such cooperation will lead to economic development and peaceful relations in a manner that is perceived as bottomup, legitimate, and - ultimately - democratic. A further

\section{REFERENCES}

Aldecoa, F., and Keating, M. (1999). Introduction. Regional \& Federal Studies, 9(1), 4-8. doi:10.1080/13597569908421066

Bache, I. (2012). "Multi-level Governance in the European Union," in The Oxford Handbook of Governance. Editors D. Levi-Faur (Oxford, United Kingdom: Oxford University Press), 628-641.

Bánkuti, M., Halmai, G., and Scheppele, K. L. (2012). Disabling the Constitution. J. Democracy 23 (3), 138-146. doi:10.1353/jod.2012.0054

Batory, A., and Svensson, S. (2019). The Use and Abuse of Participatory Governance by Populist Governments. Policy Polit. 47 (218), 227-244. doi:10.1332/030557319x15487805848586

Bermeo, N. (2016). On Democratic Backsliding. J. Democracy 27 (1), 5-19. doi:10.1353/jod.2016.0012

Börzel, T. A. (1998). Organizing Babylon - on the Different Conceptions of Policy Networks. Public Adm. 76 (2), 253-273. doi:10.1111/1467-9299.00100

Bogaards, M. (2018). De-democratization in Hungary: Diffusely Defective Democracy. Democratization 25 (8), 1481-1499. doi:10.1080/13510347.2018.1485015

Charron, N., and Lapuente, V. (2013). Why Do Some Regions in Europe Have a Higher Quality of Government. J. Polit. 75 (3), 567-582. doi:10.1017/ s0022381613000510

Charron, N., Lapuente, V., and Rothstein, B. (2018). Mapping the Quality of Government in Europe, Stockholm: Swedish Institute for European Policy Studies Report, 2108:2.

Christopoulos, D. C. (2006). Relational Attributes of Political Entrepreneurs: a Network Perspective. J. Eur. Public Pol. 13 (5), 757-778. doi:10.1080/ 13501760600808964

Dimitrova, A. L. (2018). The Uncertain Road to Sustainable Democracy: Elite Coalitions, Citizen Protests and the Prospects of Democracy in Central and assumption has been that cross-border regions are sometimes peripheral and almost always functionally harmed by national borders, and that citizens therefore will benefit from such new institutional arrangements. The resulting complex governance webs have interested scholars from many different perspectives. This article has argued that those preoccupied with legitimacy and democracy have so far focused too much on critiques of neo-liberal de-politicized arrangements favoring technocratic rule and lack of civil society involvement, and less (or not at all) with what happens when collaboration is carried out under actual de-democratizing conditions. It is time for the borderlands studies community and scholars interested in local democracy to take the threat to democracy seriously also in conceptual and theoretical terms. The suggestion in this article to adapt and utilize the rapid progress in how democracy is measured at the national level to the crossborder regional space is one way forward.

\section{DATA AVAILABILITY STATEMENT}

The original contributions presented in the study are included in the article/supplementary material, further inquiries can be directed to the corresponding author.

\section{AUTHOR CONTRIBUTIONS}

The author confirms being the sole contributor of this work and has approved it for publication.

Eastern Europe. East Eur. Polit. 34 (3), 257-275. doi:10.1080/ 21599165.2018.1491840

Erlingsson, G. Ó., and Lundåsen, S. W. (2021). When State-level Institutions Cannot Tell the Whole story: An Inquiry into Municipal Variations in Quality of Government. Governance 34, 5-23. doi:10.1111/gove.12463

Freedom House (2021). Freedom in the World 2021 Methodology. Available at https://freedomhouse.org/reports/freedom-world/freedom-world-researchmethodology.

Greskovits, B. (2015). The Hollowing and Backsliding of Democracy in East Central Europe. Glob. Pol. 6 (S1), 28-37. doi:10.1111/1758-5899.12225

Greskovits, B. (2020). Rebuilding the Hungarian Right through Conquering Civil Society: the Civic Circles Movement. East Eur. Polit. 36 (2), 247-266. doi:10.1080/21599165.2020.1718657

Halmai, G. (2011). "Dispossessed by the Spectre of Socialism: Nationalist Mobilization in Transitional Hungary," in Headlines Of Nation, Subtexts Of Class: Working Class Populism And the Return Of the Repressed In Neoliberal Europe. Editors D. Kalb and G. Halmai (Brooklyn, NY: Berghahn Books), 113-141.

Hooghe, L., and Marks, G. (2001). Multi-Level Governance and European Integration. Lanham, MD: Rowman \& Littlefield Publishers.

Hooghe, L., and Marks, G. (2003). Unraveling the central State, but How? Types of Multi-Level Governance. Am. Polit. Sci. Rev. 97 (2), 233-243. doi:10.1017/ s0003055403000649

Jakli, L., and Stenberg, M. (2021). Everyday Illiberalism: How Hungarian Subnational Politics Propel Single-party Dominance. Governance 34, 315-334. doi:10.1111/gove.12497

Keating, M. (2009). Rescaling Europe. Perspect. Eur. Polit. Soc. 10 (1), 34-50. doi:10.1080/15705850802699995

Knippenberg, H. (2004). The Maas-Rhine Euroregion: A Laboratory for European Integration. Geopolitics 9 (3), 608-626. doi:10.1080/14650040490478675 
Kramsch, O. T., and Dimitrovova, B. (2008). T.H. Marshall at the Limit: Hiding Out in Maas-RheinEuregio. Space Polity 12 (1), 31-46. doi:10.1080/ 13562570801969416

Krekó, P., and Enyedi, Z. (2018). Orbán's Laboratory of Illiberalism. J. Democracy 29 (3), 39-51. doi:10.1353/jod.2018.0043

Lynn, L. E. (2012). “The Many Faces of Governance: Adaptation? Transformation? Both? Neither," in Oxford Handbook of Governance. Editor D Levi-Faur (Oxford; New York: Oxford University Press), 49-64.

Marks, G. (1993). "Structural Policy and Multilevel Governance in the EC," in The State of the European Community: The Maastricht Debates and Beyond. Editors A. Cafruny and G. Rosenthal (London, United Kingdom: Longman), 391-410.

Medeiros, E. (2020). "The EGTC as a Tool for Multi-Level Governance," in 15 Years of the EGTCs: Lessons Learnt and Future Perspectives. Editors G. Ocksay (Budapest: Central European Service for Cross-border Initiatives), 145-168.

Medve-Bálint, G., and Svensson, S. (2013). Diversity and Development: Policy Entrepreneurship of Euroregional Initiatives in Central and Eastern Europe. J. Borderlands Stud. 28 (1), 15-31. doi:10.1080/08865655.2013.770630

Nadalutti, E. (2017). Is Cross-Border Cooperation Underpinned by an Ethical Code ofValues? A Theoretical Analysis. Reg. Fed. Stud. 27 (1), 41-62. doi:10.1080/13597566.2016.1261019

Nadalutti, E. (2020). The Ethics of Cross-Border Cooperation and its Values. Reg. Cohes. 10 (2), 41-63. doi:10.3167/reco.2020.100204

Nordic Co-operation (2021). Free Movement in the Nordics: A True story of Jobs, Commuting - and Dark Numbers. Available at: https://www.norden.org/da/ node/49223. (Accessed April 23, 2021).

OECD (2019). Making Decentralisation Work A Handbook for Policy-Makers. Paris: OECD. https://www.oecd.org/fr/regional/making-decentralisationwork-g2g9faa7-en.htm.

Öjehag-Pettersson, A. (2017). Working for Change: Projectified Politics and Gender Equality. NORA - Nordic J. Feminist Gend. Res. 25 (3), 163-178. doi:10.1080/08038740.2017.1370011

Olausson, A., and Wihlborg, E. (2018). “The Legitimacy of Political Entrepreneurs in Networks: Lessons from Local Development Projects in Swedish Municipalities," in Governance and Political Entrepreneurship in Europe. Editors C. Karlsson, C. Silander, and D. Silander (Cheltenham, United Kingdom: Edward Elgars), 229-253.

Perkmann, M. (2002). "Institutional Entrepreneurship in the European Unio," in Globalization, Regionalization and Cross-Border Regions. Editors M. Perkman and N-L. Sum (New York: Palgrave-Macmillan), 103-124.
Schakel, A. H., Hegewald, S., Danailova, A., and Gein, I. (2018). Final Report on Updating the RAI for 45 Countries. European Commission.

Sitter, N., and Bakke, E. (2019). Democratic Backsliding in the European Union. Oxford Research Encyclopedia of Politics. from https://oxfordre.com/politics/ view/10.1093/acrefore/9780190228637.001.0001/acrefore-9780190228637-e1476. (Retrieved Apr. 182021).

Stokłosa, K. (2015). "Border Regions as Laboratories of European Integration," in Microcosm of European Integration: The German-Polish Border Regions in Transformation. Editor E. Opilowska and J. Roose (Baden-Baden, Germany: Nomos Verlagsgesellschaft mbH \& Co), 16-31.

Svensson, S. (2013). Forget the Policy gap: Why Local Governments Really Decide to Take Part in Cross-Border Cooperation Initiatives in Europe. Eurasian Geogr. Econ. 54 (4), 409-422. doi:10.1080/15387216.2013.871498

Trillo-Santamaría, J.-M. (2014). Cross-Border Regions: The Gap between the Elite's Projects and People's Awareness. Reflections from the Galicia-North Portugal Euroregion. J. Borderlands Stud. 29 (2), 257-273. doi:10.1080/ 08865655.2014 .915704

Ulrich, P. (2020). "The EGTC, Transformative and Innovative Governance and National Boundaries," in 15 Years of the EGTCs: Lessons Learnt and Future Perspectives, Central European Service for Cross-Border Initiatives. Editor G. Ocksay, (Budapest: CESCI), 169-198. https://legalaccess.cesci-net.eu/en/ milestones/milestone-no-5/egtc-eu-legal-instrument/.

V-Dem (2021). Democracy Report 2021. Autocratization Turns Viral. Available at: https://www.v-dem.net/en/publications/democracy-reports/.

Conflict of Interest: The author declares that the research was conducted in the absence of any commercial or financial relationships that could be construed as a potential conflict of interest.

Publisher's Note: All claims expressed in this article are solely those of the authors and do not necessarily represent those of their affiliated organizations, or those of the publisher, the editors and the reviewers. Any product that may be evaluated in this article, or claim that may be made by its manufacturer, is not guaranteed or endorsed by the publisher.

Copyright (C) 2021 Svensson. This is an open-access article distributed under the terms of the Creative Commons Attribution License (CC BY). The use, distribution or reproduction in other forums is permitted, provided the original author(s) and the copyright owner(s) are credited and that the original publication in this journal is cited, in accordance with accepted academic practice. No use, distribution or reproduction is permitted which does not comply with these terms. 